\title{
WRNIP1 Gene
}

National Cancer Institute

\section{Source}

National Cancer Institute. WRNIP1 Gene. NCI Thesaurus. Code C106309.

This gene is involved in both ATP hydrolysis and DNA replication. 